\title{
The Transition from Keynesian to Monetarist Economics in Australia: Joan Robinson's 1975 Visit to Australia ${ }^{1}$
}

\author{
Alex Millmow*
}

\begin{abstract}
When Joan Robinson visited Monash University in 1975 she was at the height of her fame. She had just brought out a new alternative economics textbook and was strongly tipped, in the International Women's Year, to win the Nobel Prize in economics. The Cambridge School of Economics, which she represented, was in late bloom but it was the neoclassical school that was proving resurgent and already exhibiting a strong presence at Monash. It would make for theatrics when she arrived there. Although the visit to Australia overall was only for a few months, she gave lectures to first-year students at several universities and made several public presentations. The timing of her visit was poignant, with Australia, like Britain, caught in the throes of stagflation. There was an ongoing reappraisal of macroeconomic policy. Robinson's visit occurred while Milton Friedman, too, was visiting Australia on a stockbroker-funded lecture tour to push the monetarist explanation of inflation. Drawing on her correspondence with Richard Kahn and some of the lectures and the reaction they provoked, this paper recalls Robinson's visit and assesses the impact, if any, it had upon Australian economics.
\end{abstract}

\section{Introduction}

Although there is a considerable literature on Joan Robinson's frequent visits to North American universities to incite students' interest in heterodox approaches to economics, there has been nothing on her visits to other nations, not least Australia, which she visited twice. When Joan Robinson accepted an invitation to visit Australia in 1975 it was at an interesting time, with the incumbent Labor government at a crossroads over its approach to the new problem of stagflation. It was also a time when the Australian economics profession was swinging away from Keynesianism to a new economics based upon Chicago and Virginia school perspectives. The purpose of this article is to review Robinson's visit to Australia, and her reflections on Australian economics at the time, particularly at Monash, then arguably the country's leading economics department.

The paper is divided into three parts. First, there is some background on the Monash economics department, which was the primary host for Robinson's visit. The second part of the paper recalls Robinson's observations on her hosts at Monash, the general level of economics education in Australia and the country in general. The paper concludes with an ironic, rather telling, sequel to her visit.

\section{The Setting - the Monash School of Economics}

At the time of Joan Robinson's 1975 visit, Monash University possessed one of the leading and certainly the largest economics department in Australia. It had also become influential in policy-making circles. Much of it was due to the efforts of Donald Cochrane, a Cambridge-educated Australian economist, who from 1961 had been the Foundation Professor of Economics and founding Dean of the Faculty of Economics and Politics. Cochrane's strength lay in macroeconomics and 
econometrics, and he set out to make Monash a pacesetter in the fields of economics and quantitative economics (a hitherto neglected area of study in Australia). To that end, the faculty boasted Alan Powell, one of the first Professors of Econometrics appointed at an Australian university. The first-year politics unit was compulsory for all Bachelor of Economics students until 1975, giving students a good grounding in public policy formation. At the postgraduate level there was a stress upon coursework, which meant that the training in economics at Monash was rigorous. Cochrane's faculty grew quickly from 57 students in 1961 to 1,400 in 1968. By 1966 the number of undergraduates admitted to the first year of the economics degree reached 500 and held at that level, making it the largest annual intake of undergraduates of any economics faculty in Australia (Cochrane 1968, p. 1). So popular was the Bachelor of Economics degree that there was keen competition for places. By the early seventies Cochrane headed a faculty of over 100 staff, including 12 chairs spread over two departments-economics and politics. Many of the first cohort of economists hired were University of Melbourne-trained economists who had then gone abroad to pursue postgraduate studies before returning home. In a break with tradition, Australian economists now headed off to North America instead of Cambridge, Oxford and the London School of Economics.

As part of his ambition to make Monash Australia's leading school of economics, Cochrane invited eminent economists to visit the campus. He diverted funds saved from not employing second-class academics to achieve this (Williams 2007, p. 56). The astonishing flow of distinguished international visitors gave Monash students and staff exposure to a veritable Who's Who in economics. Among the glitterati who came were Colin Clark, Robert Clower, John T. Dunlop, Sir John Hicks, T. W. Hutchison, Harry Johnson, Ron Jones, Lawrence Klein, Tjalling Koopmans, Anne Krueger, Mark Perlman, Edward Shaw, Hiro Uzawa, William Vickrey and Alan Walters. Dietrich Fausten, who was one of Harry Johnson's doctoral students, recalled that apart from being a great networker, Cochrane had 'lots of money' to 'create very attractive terms for these visitors'. Harry Johnson told Fausten he felt Monash was 'a first-rate department'.

Another demonstration of this prominence was the Annual Monash Economics Lecture, which was also subsidised by the Melbourne Stock Exchange and the Institute of Chartered Secretaries and Administrators. It was always given by an eminent economist or a leading Australian public figure. The first lecture, in 1967, was given by Australia's Prime Minister Harold Holt and was entitled 'Australia Advances'. Sometimes, though, it was one of Monash's international visitors who took to the podium and addressed some contemporary concern. Harry Johnson, for instance, spoke in 1969 on 'The International Monetary Crisis' while in 1972 Robert Clower spoke on 'The Ideas of Economists'. In 1971 Alan Walters spoke on 'A Failure of Economics?', explaining how economists had not developed a valid theory of the monetary dynamics of the short-run adjustment in the pricesoutput process. In 1974 Dunlop addressed a current Australian concern in his lecture on 'Inflation and Incomes Policy'. It attracted an audience of 800.

It has been argued that Australian economics was not as exposed to the 'grand neoclassical synthesis' as elsewhere, making it more receptive to Post Keynesian influences (King 1997, p. 300). Many Australian economists, even in the mid-seventies, were still Keynesian and did not accept the full gamut of the monetarist orthodoxy (Hughes 1980, p. 44). They were 'mostly confirmed Keynesians' in their belief in the efficacy of fiscal policy (Nevile and Stammer 1972, p. 9). During the sixties Monash, like the rest of the Australian economics 
profession, followed something close to the Cambridge line on Keynes (King 1997, p. 301). The Monash economics department itself was a 'large multi-professorial department' comprising administration, accounting, economics, economic history and statistics (Cochrane 1968, p. 2). It was also a tolerant, pluralistic one until 1973/74, when it began to undergo a sea change in philosophy. Things had changed when Cochrane left the department to become full-time Dean and two professors left in quick succession. Joe Isaac went to the Arbitration Commission and Fred Gruen, professor of agricultural economics since 1964, went to join the Australian National University (ANU) at the end of 1971. Their replacements were more neoclassically inclined. Ian Ward, who had been at the department since its inception, suggested that the new appointments were at the behest of higher authority to help quell the student unrest that to a large extent characterised Monash-campus life over this period. ${ }^{3}$ Peter Riach rejects this view, stating that the appointments were driven by the free-market views of Richard Snape and Powell. ${ }^{4}$

During the late 1960s both at Monash and elsewhere there had been some departmental reaction to student agitation about changing the economics syllabus. Gruen (1971), then Acting Dean, tried to distil exactly what the students' protests were about, prior to accepting the prestigious offer of a chair at the ANU. His position at Monash had become a little strained after he established some institutional apparatus whereby students could air their grievances concerning the syllabus. Don Cochrane had encouraged Gruen to take the ANU post because he found him too 'independently-minded'. ${ }^{5}$ Gruen's replacement was another agricultural economist, Ross Parish. Both Dietrich Fausten, who was the Head of the economics department in 2008, and Peter Riach, who was a Reader at Monash in the seventies, recall that it was Parish, with his exposure to Chicago school perspectives, who became the 'driving force' behind the rightward shift of the faculty in the 1970s. ${ }^{6}$ It would set Monash apart from other Australian universities. Riach recalls that Alan Powell played a significant role in attracting Parish to Monash. ${ }^{7}$ Rodney Bourke, who undertook an honours degree in economics there between 1971 and 1974, recalls that there were 'idea wars' going on between rival groups within the faculty. ${ }^{8}$

A member of the Mont Pelerin Society, Parish came to Monash in 1973 from the World Bank, having previously held a chair in agricultural economics at the University of New England. He had studied under Milton Friedman at Chicago and was delighted to report that his old instructor remembered him some twenty years later (Hogbin 2002, p. 63). He had an interest in microeconomic analysis, with a particular focus on applying the basic principles of price and resource allocation theory to other spheres of economic and social activity like non-price rationing mechanisms, the environment and recycling, and consumer protection (Hogbin 2002). Parish's leitmotiv was to make the Monash department aware of the power of free markets to promote human welfare by creating incentives for producers to strive to satisfy the demands of consumers. He regarded political processes and governments as compromised by organised interest groups that were determined to gain at the expense of others in society. Ward recalls that, upon first meeting Parish, the new appointee believed Monash staff and students 'were all socialists because they believed in progressive taxation'. ${ }^{9}$ Parish was not enamoured with Cambridge, stating that he would never appoint anyone trained in or with views sympathetic to it. ${ }^{10}$ Consequently, patronage and favour fell on those with similar views. While there were heterodox economists on the staff, fourth-year honours students were directed to cost benefit analysis (Parish), law and economics 
(Maureen Brunt), trade and welfare (Richard Snape) and public goods (John Head, who had Keynesian sympathies), while the compulsory microeconomics was taken by the dedicated neoclassicist, Yew-Kwang Ng, and macroeconomics by the monetarist-leaning Lachlan McGregor. Monetarism is the macroeconomics equivalent of neoclassical microeconomics insofar as it rejects discretionary government intervention in the workings of the economy.

The chairman of the economics department at the time of Robinson's visit was Snape. He had made important contributions in trade theory by looking first at product variety and the role of economies of scale, which led to the conclusion that in theory at least the argument for free trade was a complex one. According to Peter Kenyon's (2002) obituary, Snape had been 'a major pillar of the intellectual structure that made Monash economics one of the finest university economic departments that Australia has ever had'. Those of heterodox opinion would certainly beg to differ. While there were other possible factors at play, the Monash department, with Snape at its head, seemed to shun the appointment of heterodox economists. Ian Ward recalls that a general equilibrium theorist, David Evans, was driven out because, while he pursued the right methodology, he purveyed the wrong ideological line. ${ }^{11}$

In the 1970s 'Monash Economics' became renowned for its applied policy work and in the latter half of that decade it became known for colouring that advice with an ideologically conservative streak. This reflected, in particular, the advisory contributions made by Snape, Powell and Parish. It enticed one member of the department, Keith Frearson, to comment wryly: 'Everyone at Monash seems to be policy-making in some way or another. I think the time is ripe for an article on the "The Economic Effect of Economists!",12 The department increasingly moved away from Keynesian economics to embrace the perspectives of the Chicago and Virginia schools with their choice-theoretic models. When the Stanford-educated Michael Porter was appointed to Monash in 1977 and later headed the newlyestablished Centre for Policy Studies, it, in turn, became the hard policy edge of the Monash department. Besides advocating the float of the Australian dollar, Porter was one of the first Australian economists to argue that fully subsidised tertiary education be replaced by a student loans scheme, since most of the beneficiaries under the existing system were drawn from higher socio-economic groups. ${ }^{13}$ In 1978 Parish and McGregor attended the first Centre for Independent Studies seminar, entitled 'What Price Intervention? Government and the Economy’ (Lindsay 1996, p. 18). ${ }^{14}$ Cliff Walsh, appointed from the Australian National University in the same year, would later become economic adviser to Prime Minister Malcolm Fraser.

Robinson's invitation to visit Monash in 1975, as in 1967, came from Frearson. ${ }^{15}$ An ex-serviceman, Frearson had attended Robinson's lectures in the 1950s on what was to become The Accumulation of Capital and had fallen under her spell (Harcourt 2007, p. 107). He was to play a significant role in the unfolding drama of Robinson's 1975 visit. It was Frearson, too, who had first raised the idea of inviting Robinson out to Australia in the sixties. He wrote to Geoff Harcourt: 'I do wish Joan could come out here for a trip', adding that Trevor Swan would, if he met her, quickly become 'a devotee'. ${ }^{16}$ Robinson, had, in fact, already encountered some Australians at Cambridge. She had, of course, befriended Geoff Harcourt and had also been a tutor to Max Newton, later to become a firebrand economics commentator. According to Michael Schneider, who was at Cambridge during the period 1956-59, Robinson was, along with Brian Reddaway, the most caring of Cambridge teaching staff with regard to the welfare of students from abroad, particularly from the Commonwealth. 
Earlier in 1967 Robinson had stayed at Monash for three weeks, at a time of intense student agitation caused by the Vietnam War. There was some controversy when Robinson lent her support to students collecting funds for the Vietnamese National Liberation Front. She defended their actions in the press, declaring 'The students have a right to their own opinion ... I have spoken to these students and found them spirited young people with fresh ideas'. ${ }^{17}$ Robinson gave the students further encouragement in an interview she gave in the student newspaper, Lot's Wife, though she did not suggest changing the economics syllabus. ${ }^{18}$ She delivered some classes in Frearson's third-year economic growth subject. According to Riach, at the time a young lecturer in labour economics and income distribution theory, Robinson supported the students. As a young student, social activist and advocate, Rhonda Galbally (2004, p. 79) recalled being mesmerised when Robinson approached the podium to give a lecture, 'tall and elegant ... dressed in long trousers with white hair'. Ken Aldred, then a third-year economics student, vividly recalls Robinson's lecture to an overflow audience as the most outstanding scholastic memory of his undergraduate years at Monash. He recounts how a beaming Frearson escorted her into the lecture theatre 'almost like a proud younger brother with his big sister'. ${ }^{19}$ Aldred recalls that Robinson had a mesmerising presence, captivating the audience as she explained the true meaning of Keynes. Unlike the subsequent 1975 visit there was no correspondence from Robinson to her close colleague at Cambridge, Richard Kahn.

Joan Robinson's second visit took place when the student body at Monash had become more sedate. The Vietnam War was over and a reformist Labor government was in power for the first time in 23 years. As part of its platform the Whitlam Government had abolished university fees in 1974. While her reputation derived from being the 'very first that ever got into the jar labelled left-wing Keynesian', she would shortly confront a smattering of acolytes drawn from the Virginia and Chicago schools (Dow 2003, p. 163). On some of her American tours Robinson loved to take the fight up to her opponents. She had famously given the American Economic Association's Richard T. Ely lecture in December 1971. It was entitled 'The Second Crisis in Economic Theory'. The first crisis had had been the interwar one of an effective demand failure. The new crisis concerned the lack of a suitable framework to deal with the new problems of poverty, racism, urban congestion, pollution, rapid population growth and war. The lecture met with a standing ovation.

Two years later Robinson along with John Eatwell published the introductory textbook An Introduction to Modern Economics, which she hoped would be 'a lifeline' for those dissatisfied with conventional economics. ${ }^{20}$ On sabbatical from Monash, Frearson spent it mostly at Cambridge and had attended the book launch in September 1973 where Robinson gave a 'little speech' marking the venture. It moved Frearson to record 'The thing that is marvellous about Joan is her genuine passionate concern for the subject. She really is a noble woman'. ${ }^{21} \mathrm{~A}$ few months earlier, Frearson had been joined at Cambridge by a colleague from Monash, Courtney Wright, who was to be at odds with Robinson. Frearson told Harcourt how Robinson had 'been tearing a few strips off Courtney-he is a bit more obtuse and pedantic than I thought'. 22 In January 1974, after wistfully reflecting upon 'my best year at Cambridge' Frearson moaned that 'I don't at all relish the prospect of returning to those Pretentious and Unimaginative people at Monash'. 


\section{Enter Joan}

Keith Frearson met Robinson, then 72, when she arrived in Perth in early March 1975 for her two-month sojourn in Australia. Robinson would spend most of her visit at Monash, along with a fortnight at the University of Adelaide, and, on the way home, a week at the University of Sydney. There she would be chaperoned by Ted Wheelwright, who had, through the office of the Dean of the Faculty of Economics, Geelum Simpson-Lee, invited her out to visit the year before. ${ }^{24}$ Wheelwright shared her interest in Maoist China and had been at the forefront of the struggle to establish a course in political economy at the University of Sydney. In Perth Frearson gave her correspondence that had already arrived at Monash, but none from Richard Kahn, who would send her news clippings on British political and economic news along with faculty gossip from Cambridge. Robinson immediately scribbled off an aerogram to Kahn, saying how she was impressed with Perth, presciently calling it the 'California of Australia'. ${ }^{25}$

She had arrived in Australia at a time of considerable political and economic turbulence, with the nation beset by the new problem of stagflation. Inflation was running at a reported $17 \%$ and was the focus of national attention. At the start of the year a leading news weekly, The National Times, had written of a capital strike, with a collapse in private investment spending because of a lack of faith in the government's handling of the economy. Jim Cairns was Federal Treasurer but his department, the Federal Treasury, along with the Reserve Bank of Australia, was beginning to break away from conventional Keynesian economics and perceiving inflationary expectations as the key force behind wage inflation. ${ }^{26}$ There was also increasing concern about the link between the budget deficit and money supply growth. A Treasury briefing to the Cabinet in January was blunt: 'The economic situation is very bad. It is very bad, not only because of the evident weaknesses in the economy, but because there are no quick solutions' ${ }^{27}$ Cairns still believed that unemployment was a greater scourge than inflation and wanted to pump prime the economy, even though the budget deficit was already sizable. In early May Cairns admitted that the 'main problem facing Australia today is inflation', but in a Budget Strategy paper issued in the same month, he argued that it was better to lose office than to pursue policies that would increase unemployment (Strangio 2003, p. 364). In a television interview aired on the national network Cairns criticised his own departmental staff for holding views opposed to his own. Australian macroeconomic policy was at an impasse.

Robinson travelled across the continent to Melbourne by train, stopping off briefly at Adelaide where she met up with Harcourt. After a total of three nights on the intercontinental train she arrived at Monash on 5 March. She met Colin Clark, who was also a Research Fellow there. ${ }^{28}$ She agreed to give two seminars on her 1974 'History versus Equilibrium' paper and volunteered to assist Martin Watts, who had just been appointed at Monash to teach the compulsory third-year subject 'economic growth' along with the fourth-year honours subject 'capital and growth'. With only a limited background in these areas, Watts spent part of the preceding months boning up on theory. Robinson took a lecture in each of these units, making it a daunting proposition for Watts since it was extremely unlikely that a question would come from the students unfamiliar with the subject matter. Silence predictably followed each of her lectures. In the 'capital and growth' lecture Watts took his life in his hands by suggesting that, despite the logical flaws of the 
neoclassical growth model revealed by the Cambridge controversies, it was still appropriate to teach it. ${ }^{29}$

It took only a few days until Robinson reported to Kahn back at Cambridge, with typical bluntness, that the Monash faculty was 'prickly defensive new classics and monetarists but there are a number of dissidents, who however seem rather feeble'. ${ }^{30}$ The heterodox elements at Monash then included Frearson, Riach, Ward and Watts, who were all wary of general equilibrium approaches. She told Kahn how Clark was due to give a seminar on the rise of money wage rates caused by the rise in the price of capital goods. Robinson attended it and told Kahn that she found Clark's explanation rather 'dotty'. ${ }^{31}$ Robinson must have savaged Clark, because she wrote that he was 'quite good natured under attack. There is something rather sweet about him and as a personality he is much better value than anyone else here'. 32

Robinson duly presented her seminar on 'History versus Equilibrium', in which she argued that neoclassical supply and demand analysis had no capacity to handle historical as opposed to logical time. This dismissal of the microfoundations of the discipline was a challenge to some faculty members, including Courtney Wright. At one stage Robinson suggested that if they were not able to accept her arguments, they should move to another room and continue their discussions there. She did not deny that orthodox supply and demand analysis should be taught, but argued that if it were taught, it should be taught in a 'history of economic thought' context. Afterwards, at an official dinner function, Robinson got into a ferocious argument with Yew-Kwang Ng and Colin Gannon about the vexatious matter of the meaning of capital. At this stage Robinson was no longer prepared to re-argue the capital controversy as she believed that she had won the debate with Paul Samuelson (Harcourt 1972). Ng and Gannon, however, reopened the debate. Peter Riach recalled Ng grabbing a chair and saying 'This is capital!' Robinson initially ignored the bait but then started to debate with them, which Riach, listening in, felt she won. Her victory was ruined a little by Frearson abusing his two colleagues and letting them off the hook somewhat. ${ }^{33}$ Robinson reported back to Kahn how a 'young neoclassic who was at first supercilious but was made gradually to concede my point. However I suppose he will slip back into teaching the same stuff all the same'.

A few days later Robinson gave a lecture at the University of Melbourne on capital theory. She told Kahn, though, that 'no-one there seemed to have heard of the “capital” controversy'. Robinson's next engagement at Monash was when she spoke on 'the Crisis', by which she meant a re-run of the themes contained in her Richard T. Ely Memorial Lecture. She made the usual refrain to Kahn: 'As usual, the opposition won't take me on but I am sure they tell their pupils not to listen to me or they will fail their exams'. ${ }^{35}$ If Monash was indeed the most eminent school in Australia, Robinson was little moved by it. Before she left for Adelaide she told Kahn how she had been 'carrying on a blitz on the undergraduate teaching here which is at the level that prevailed in Cambridge in 1929. No one can answer me but most of the professors just refuse to take anything in and the students are afraid of what grades they will get. However a number of young teachers are strongly supporting me'. ${ }^{36}$

Robinson would spend two weeks at the University of Adelaide with Harcourt, the visiting British economist John Vaizey and Brian Pollitt. Their company would be 'a bit more amusing than here'. ${ }^{37}$ Pollitt, a development economist, had also earlier applied for a position at Monash but was unsuccessful. 
After Adelaide, Robinson returned to Monash to complete a week of teaching before heading off to Sydney. From Adelaide Robinson reported that it was indeed a more 'congenial atmosphere', but that 'the level of economics however is not much better' ${ }^{38}$ John Hatch vividly recalls Robinson criticising her closest supporters at Adelaide, especially their reluctance to use her textbook. ${ }^{39}$ The fact that the revolutionary textbook had failed to supplant mainstream competitors like Samuelson and Richard Lipsey annoyed her (King and Millmow 2003). Robinson told Kahn that Harcourt had not much influence on the teaching of economics at Adelaide. ${ }^{40}$ Vaizey, the professor of economics and Head of the Department of Social Sciences at Brunel University, was one of Joan Robinson's old students, with a 'life-long admiration' for her (Howarth 1986, p. 2). He was a Centenary Visiting Fellow at Adelaide, which had involved two sojourns at the university, firstly in the spring of 1974 and autumn of 1975 . In a semi-autographical piece he had just written he declared that Cambridge economics:

was a subject that was on the move ... Evidently, once the question about the purpose of economic activity was asked and then looked at through philosophy as it was revealing itself, at the social structure as studies were beginning to reveal it, and at the political context, it followed that work in economics was likely to go in several directions. It could become a narrow self validating predictive 'science', it could become a wide ranging discipline, purporting to ask 'big' questions about 'big' issues like sociology. Or it should go through the hard work of rethinking its basic assumptions. (Vaizey 1986, p. 118)

While this last path 'was rock-strewn and dusty ... its intellectual power is for me its most attractive characteristic'. For Vaizey it was the only possible route for the discipline. In September 1974 he gave the 35th Joseph Fisher lecture at Adelaide University, entitled 'Political Economy and the Problems of our Time', where he repeated these views. Only Cambridge economics, enriched with the insights of Ricardo, Marx and Keynes, would do, being more 'realistic and positive theory than neoclassical economics. He also lavished tribute on his old instructor, noting how the mainstream economists used Robinson's eccentricities both to patronise her and as a means 'designed to keep their students ignorant of her work'. He went on to praise Robinson's intellectual and political prescience:

She was the first British economist to show the irreconcilability of competitive decisions with the facts of mass manufacturing industry with its economies of scale. She was a central person in the debate that led to Keynes' General Theory and her Essays in Employment openly attest the implications of the new doctrines for inflation, international trade and regional policy. When Russia was all the rage and socialism on the up and up, she was the only serious intellectual critic of Marxist economic theory. She was the first in the fashionable theory of developing countries. She got to China before Kissinger. And now her views on wages and prices are the new orthodoxy. Not a bad record for relevance, it might be thought' (Vaizey 1975, p. 13, fn).

Meanwhile, in another lecture to first-year economics students, this time at Flinders University, Robinson told her audience 'why all that they are going to be taught is nonsense'. ${ }^{41}$ From her correspondence with Kahn it is evident that Robinson enjoyed being amongst kindred spirits and also undertaking a few bush- 
walks with Harcourt. Probably known to her though, Vaizey had written to the newly elected leader of the British Conservative party, Margaret Thatcher, congratulating her on her success and offering to help. ${ }^{42}$ Vaizey had written to Thatcher a month earlier telling her how a newspaper article he had written in the London Evening Standard bemoaning the state of Britain, particularly the bloodymindedness of the trade unions, had attracted a huge public response. He forwarded a copy to her and suggested they meet. Thatcher responded, agreeing that that there was a 'yearning to get things right again among people of many political views' ${ }^{43}$ They had shared an earlier correspondence on education matters and Vaizey knew that Thatcher was now an early convert to Monetarism, believing that inflation was entirely a monetary phenomenon and eschewing Labour's approach of income and price controls as the way to end Britain's inflation problem (Garnett 2007, p. 48).

When Joan Robinson returned to Melbourne she wrote about being 'rather depressed at returning to this city', that Adelaide was 'much nicer', and how she had 'enjoyed weaving around' with Vaizey and Pollitt. ${ }^{44}$ Nonetheless a walk in the Adelaide hills had jolted her. She told Kahn that 'Australia is uncomfortable to the mind-such totally alien country with an all too familiar suburban civilisation laid on top of it'. ${ }^{45}$ The surrounding environs where the Monash campus was set were also unprepossessing and would have added to Robinson's unease. In the last week there she gave an interview to Lot's Wife which, unfortunately, was a collage of interviews and passages taken from her forthcoming Volume IV of her Collected Economic Papers. She told her interviewers: 'The orthodox professors don't like me because I'm always making remarks about how capitalism actually works and therefore they think I'm a dangerous red ... they think economists should always be praising capitalism and teaching people how well off they are under capitalism. ${ }^{46}$

Robinson did not know that the last weeks of her Australian interlude were to assume a higher profile. One of her great opponents, Milton Friedman, had begun an Australian lecture tour. A Sydney stockbroking firm, Constable and Bain, under the leadership of Maurice Newman, had arranged and financed his trip (Friedman and Friedman 1998, pp. 427-8). Newman was a friend of Friedman and was also 'a convinced libertarian, a member of the Mont Pelerin Society'47 (Friedman and Friedman 1998, p. 428). Newman was keen to initiate more debate into the causes of inflation, as he felt that the local discussion had become staid and wanting. ${ }^{48}$ Friedman was both messiah and showman. The Economist (1970) had once described him as 'able to argue the hind leg off a horse'. He was also an adept television performer. Friedman appeared on the ABC-TV program Monday Conference on 14 April 1975. It was, a little ironically, telecast from Monash University’s Mt Eliza Business School just outside Melbourne. In the audience were senior Australian economists who came away mostly convinced that much of Friedman's analysis and policy was probably correct (Courvisanos and Millmow 2006). Keith Frearson sparred with Friedman over public sector spending and, like most critics, came off second-best. Robinson was both bemused and irritated by the sight of 'Milton on the tele'. His rapid-fire views on what lay behind inflation were 'To anyone with any insight a shocking piece of charlatanism but most of the novices were no doubt impressed'. ${ }^{49}$ On this Robinson was startlingly correct; the program was recast six weeks later and, like the visit itself, it did shape popular and political perception in Australia about what lay behind inflation. Later, a booklet celebrating Friedman's visit to Australia was circulated. Robinson told Kahn about Friedman's sleight of hand: 'He maintains that trade unions do not cause inflation. Inflation means an increase in the quantity of money (that is - the amount of money 
that people have to spend) the qualifying phrase being mentioned as an aside'. She closed by telling Kahn that she might appear on a forthcoming edition of the same program, 'so I may get a crack at him, ${ }^{50}$ Robinson farewelled Monash on 18 April and travelled to Sydney by train, briefly stopping off at Canberra where she met and stayed overnight with one of Colin Clark's sons, Gregory.

It was an exciting time at the University of Sydney, with a raging feud going on between orthodox and radical economists (Stilwell 2006). ${ }^{51}$ Chaperoned by Ted Wheelwright, it would be a busy week for Robinson as she fulfilled two public engagements along with two university seminars and lectures to students. She gave the history versus equilibrium seminar at both the University of Sydney and the University of New South Wales. At the former she was riled by Debesh Bhattacharya who addressed her as 'Lady Robinson'. The first public engagement was to give the Seventh R. C. Mills Memorial Lecture at the University of Sydney on 23 April. She entitled it 'Contradictions in Capitalism Today: Where Do We Go from Here?' The lecture, long thought to have been lost, was recently unearthed and reconstructed using a text transcribed from a recording of the lecture. The transcript, however, was incomplete, containing large omissions, and was only made intelligible by editing work undertaken by Peter Groenewegen (2004, p. 10), who used remarks made by Robinson at that time to fill in the gaps.

The Mills lecture was a bleak reprise of the themes raised in her Ely Memorial lecture but updated to focus upon the inflationary crisis in both Britain and Australia. The inflation was yet another manifestation of the inherent contradictions within capitalism. The inflationary problem had undermined bastard Keynesianism and along with it notions of a trade-off between inflation and unemployment. Creating unemployment, Robinson held, was inherently inflationary as it reduced aggregate output. She also skewered Friedman's recent views on inflation, aired on Australian television, showing how he played a 'verbal trick' on viewers by making the effective quantity of money equivalent to the flow of expenditure. The new circumstances had resulted in a newer version of Michal Kalecki's political business cycle. The inflation that Australia, along with Britain, was suffering was the outcome of a struggle between labour and capital over relative income shares. It was to Robinson an insoluble problem, though the inherently natural outcome of a fully employed economy. Simply put, for a market economy to grow it had to generate profits, and this led to a struggle over shares, which undermined the system. It would only disentangle if there were some additional factor thrown into the equation. 'Britain' she told Kahn in her last letter from Australia was in a 'cataclysmic' state and something would soon give. ${ }^{52}$ If the government did decide to deflate the economy, trade unions would become more militant. She dismissed the idea that a Western government would have the tenacity to do so, since it would rewrite the political and social contract that had underpinned the postwar Keynesian consensus. In this she was proved abysmally wrong. A month later the former editor of The New Statesman, Paul Johnson, warned that 'Trade unionism is killing socialism in Britain' (Garnett 2007, p. 224). Vaizey and Robinson would also have felt dismay at how riotous wage inflation was endangering a democratic socialist Britain. Nearing the end of her Mills lecture Robinson offered a way out of the impasse by suggesting a new industrial relations climate which would generate cooperation between workers and enterprises to shut out militant trade union leaders and egotistical managers.

Robinson told Kahn that, apart from her one 'big lecture', she gave a televised interview on the Monday Conference program that was recorded the day 
before the R. C. Mills lecture. It was recorded at the Sydney Opera House, which was 'quite fun'. She found the proceedings, though, 'rather tiresome', perhaps due to the detractors and opponents within the audience and her struggle to get over her argument about what causes inflation. ${ }^{53}$ She had to overturn the monetarist line about the central importance of the money supply in arresting inflation. Several in the audience did not catch her argument against destroying the quantity theory. Maurice Newman (organiser of the Friedman visit) asked Robinson about the primacy of the money supply and, receiving what, to his mind, was an unsatisfactory response, remarked high-handedly: 'I think we'd be here all night debating backwards and forwards and I'm sure that we wouldn't achieve much purpose because I couldn't convince Professor Robinson, and I'm sure she couldn't convince me'. ${ }^{54}$ There were several of her supporters in the audience, including students and academics from the Political Economy movement at the University of Sydney.

Amidst her weariness Robinson's wit still shone. After a brief foray upon her economic philosophy and methodology the presenter, Robert Moore, turned to the 'substantial issue and to Milton Friedman I suppose', and asked her, 'How important is control of the money supply in curing inflation?' Robinson retorted 'Well, very much less than Milton Friedman makes out!'55 'Friedman's great attraction', she went on, was to argue that inflation was all to do with the quantity of money, '... so you don't have to face this deep and divisive political problem, and that is why people clutch at straws, ${ }^{56}$ When a member of the audience asked whether she would describe herself 'as a Marxist or a Socialist or a Keynesian', she replied 'that I would describe myself as a reasonable being' ${ }^{57}$ Her tiredness came through in being dismissive with student enquiries about the existential debate about capitalism versus socialism. When Moore asked whether economic theory could address the problem of stagflation, Robinson demurred, saying that all economic problems are political questions. When given the same opportunity Friedman grabbed it with both hands.

Robinson's last word on Australia before she boarded the plane for Japan was to tell Kahn 'I have been disappointed by Australia on the whole as I had expected it to be less smug and narrow-minded than when I was here last but if anything the other way. However it has been quite agreeable as a visit ${ }^{58}$ Her guest appearance on Monday Conference was broadcast on the following Monday 28 April, the day after Robinson had left for Tokyo. One can only speculate about what the television audience made of her performance. Some years later Heinz Arndt felt that Robinson's aggregate contribution to economics merited the Nobel Prize. He summed up the Robinson persona thus: 'I think Joan represents a tradition of English upper class female ideologues from Harriet Martineau to Beatrice Webb who have applied good minds to the exposition of causes to which they have been emotionally attached with a fury driven by a puritanical guilt complex and an aristocratic disdain for little people and therefore for democracy. ${ }^{, 59}$ The last phrases referred to Arndt's disdain and that of many others, for that matter, for Robinson's support for Mao.

\section{$4 \quad$ Legacy and Sequel}

The visit of Robinson to Australia attracted little media attraction. One prominent economics commentator who did notice it and accurately captured the content of economics regretted that it had been overshadowed by the circus surrounding Friedman's visit (McGuinness 1975). It had been Friedman who had been fêted by 
business groups and met with high economic officials and enjoyed considerable publicity. In contrast, the Robinson visit had been muted, and the grand dame of economics some times appeared tired and irritable with her guests. When asked what she recommended for the Australian economy, she curtly dismissed the question, saying that it was not her place to comment. Friedman would have answered more adroitly and got his point across.

The fact was that her visit was the last hurrah of 'the spirit of 1968'. Perhaps she noticed it in the students' faces. While there was student interest, there was no great fervour in the air. She certainly encountered it with the staff at Monash and elsewhere. Economics was turning to Chicago rather than Cambridge. The neoclassical resurgence was in full swing. Events in Australia moved quickly after her visit. Her apprehensiveness about the seductive techniques of Friedman proved well-founded. Cairns was removed as Treasurer in June and replaced by Bill Hayden, who had for some time accepted the importance of curbing inflationary expectations by reining in public expenditure. 'Fight inflation first' became the new mantra. The next year Australia made further strides down the monetarist path by being one of the first developed countries to attempt a fairly rudimentary form of money supply targeting to curb inflation (Guttman 2005).

There were some interesting reverberations at Monash following the Robinson visit. Snape gave a graduation address in May 1975 to economics and commerce students, defending mainstream economics against the 'stirring' words of radicals who felt that Australian economics training was conservative in impact. There was nothing intrinsically wrong with disagreement among economists, Snape argued ${ }^{60}$ Nor was he unnerved by it. He went on to address another criticism of economics, namely, the response to stagflation. It was unfair to attack mainstream economics, Snape held, if there 'is no politically feasible solution to the problem at the moment'. He then coyly added: 'However I hazard the view that political feasibility will be changed by the process of inflation' ${ }^{61}$ Snape was reading the political tea-leaves and predicting-rightly as it turned out-how Australian economic policy would shortly thereafter accept the monetarist agenda of defusing cost push inflation by disinflation. Snape was also alluding to what would become known as the real wage overhang thesis, which held that Australian real wages had grown faster than productivity (Snape 1979).

There was another, more ironic, sequel to Robinson's visit to Monash which, in a sense, said much about the way the world was turning. When Monash's first Vice-Chancellor, Louis Matheson, announced his resignation, the University Council had gone looking for a high profile successor. Vaizey, who had been passed over for the position of Vice-Chancellor at Brunel, applied for the Monash position and won the Council's unanimous approval. ${ }^{62}$ The student newspaper Lot's Wife greeted the appointment with the reservation that 'It seems a little too good to be true. It probably is'. ${ }^{63}$ When Vaizey was shown the Lot's Wife headline, 'Commie elected VC', he told Harcourt that 'the students' expectations were high and will not, in the event, be realised ${ }^{64}$ In the same letter he spoke of wanting to 'feed Vicky Chick's name into the machine'-code for a Monash appointment. He also spoke of appointing six new Deans. ${ }^{65}$ According to Harcourt, the Monash economic professors were appalled at the Vaizey appointment. ${ }^{66}$ Frearson and Riach, however, were 'excited' at the prospect of Vaizey coming. ${ }^{67}$ The ViceChancellor-elect, though, was having reservations about coming to Melbourne. Writing from Latin America, he sounded out Thatcher on whether she would be interested in hiring him as a full-time economic adviser. Thatcher told Vaizey that 
her party did not have 'the means to take on someone of your distinction' and advised that he should accept the 'Australian offer' for now. ${ }^{68}$ Vaizey's reply was a rather profound one and signified his final disengagement from the British Labour Party. He argued that Britain 'has been on the wrong lines since 1941', and suggested that a 'major intellectual and moral effort is necessary to rescue our country from what seems abroad to be a totally catastrophic course'. He closed by stating that Thatcher was the 'only person who can try to push us on to a different course'. After some procrastination Vaizey elected to stay in London and Monash withdrew the job offer. In November of that year, in what he called the 'scoop of the century', Vaizey interviewed Robinson for a BBC radio program devoted to leading contemporary economists and the history of economic thought. ${ }^{69}$ Despite Harcourt's representations to the ABC, neither the program nor the series was ever broadcast in Australia.

* School of Business, Post Box 663, University of Ballarat, Ballarat Vic 3353, Australia. Email: a.millmow@ballarat.edu.au.

\section{Notes}

1 I would like to thank the following for their input into the making of this paper without incriminating any for any error: Ken Aldred, Rodney Bourke, Dietrich Fausten, Peter Groenewegen, Geoff Harcourt, John Hatch, Joe Isaac, Rob Jolly, John King, Peter Kriesler, John Lodewijks, Keith Norris, Peter Riach, Graeme Richards, Michael Schneider, Gus Sinclair, Frank Stilwell, Tim Thornton, Ian Ward, Martin Watts and Yew-Kwang Ng. I would also like to thank those who attended a seminar on this topic at the Department of Economics at La Trobe University and also at the Department of Economics, Monash University. This paper was presented at the $21^{\text {st }}$ HETSA Conference at the University of Western Sydney and I would like to thank all who commented on the paper there. I would like to thank the scholars and Provost of King's College, Cambridge, for allowing me to cite the papers of Joan Robinson and Richard Kahn. Special thanks to Cheryl Hoskin, Special Collections Librarian, University of Adelaide, for guiding me through the Harcourt papers. Lastly, I would like to thank the forbearance of the two anonymous referees who reviewed this paper.

2 Author's interview with Dietrich Fausten and Gus Sinclair at Monash University, 2006.

3 Interview with Ian Ward conducted with the author and Tim Thornton, April 2008.

4 Personal communication with the Peter Riach, 23/1/09.

5 Ibid.

6 Personal interview with Dietrich Fausten 2006 and personal communication from Peter Riach, n.d.

7 Personal communication with the author.

8 Personal communication with Rodney Bourke, August 2007.

9 Interview with Ian Ward, April 2008.

10 I owe this comment to Geoff Harcourt in an email communication dated $16 / 4 / 2008$.

11 Interview with Ian Ward, April 2008.

12 K. S. Frearson to G. C. Harcourt, 29/9/1973, Geoffrey C. Harcourt Papers, University of Adelaide (hereafter GCH, UA).

13 'Student Loans Scheme would reduce inequality', Monash Reporter, June 1977, p. 8. 
14 The Centre for Independent Studies, founded in 1976, is, like the Institute of Economic Affairs in Britain, an important libertarian think-tank in Australia and publishes the journal Policy.

15 K. S. Frearson to J. V. Robinson, n.d., JVR/7/147, Joan Violet Robinson Papers, Modern Archives Centre, King's College, University of Cambridge (hereafter JVR KCC).

16 K. S. Frearson to G. C. Harcourt, 19/5/1964, GCH, UA.

17 'Supports Monash students' bid', The Age September 13, 1967, pg.15.

18 R. Jolly and R. Bluer, 1967, 'Joan Robinson Interviewed', Lot's Wife, 7(13), October 10, pp. 12-13. Rob Jolly, a first-class honours graduate in 1968, later became an ACTU advocate and Treasurer in the Cain Labor Government in Victoria.

19 Personal communication with Ken Aldred, December 2007. For some 20 years Aldred was a Member of the House of Representatives as a member of the Liberal Party of Australia.

20 K. S. Frearson to G. C. Harcourt, 28/9/1973, GCH, UA.

21 Ibid.

22 Ibid.

23 K. S. Frearson to G. C. Harcourt, 9/1/1974, GCH, UA.

24 G. A. J. Simpson-Lee to J. V. Robinson, n.d., 1974, JVR/7/417, KCC. Much earlier Simpson Lee had gone to Cambridge but failed to complete his doctorate.

25 JVR to RFK 3/3/1975, Richard F. Kahn Papers, Modern Archives Centre, King's College, University of Cambridge /13/90/10/183 (hereafter RFK, KCC).

26 A year earlier Cairns had informally asked Geoff Harcourt, who had been advising the Labor Government on its 1974 federal budget, to become Governor of the Reserve Bank of Australia or, failing that, head of a proposed medium-term planning unit within the Treasury. Harcourt declined both job offers.

27 National Archives of Australia: A5915/ Cabinet Submission 1534, 16 January 1975.

28 JVR to RFK, 7/3/1975, RFK/13/90/10/181, KCC.

29 Written reminiscence from Martin Watts, 11/5/2007.

30 JVR to RFK, 10/3/1975, RFK/13/90/10/176, KCC.

31 JVR to RFK, 13/3/1975, RFK/13/90/10/174, KCC.

32 Ibid.

33 Personal communication from Peter Riach, 9/10/2007. Yew-Kwang Ng of Monash

University has also corroborated this story with the author, November 2007.

34 JVR to RFK, 13/3/1975, RFK/13/90/10/175, KCC.

35 JVR to RFK, 18/3/1975 RFK/13/90/10/169, KCC.

36 JVR to RFK, 27/3/1975, RFK/13/90/10/164-5, KCC.

37 JVR to RFK, 24/3/1975 RFK/13/90/10/166, KCC.

38 JVR to RFK, 2/4/1975, RFK/13/90/10/160, KCC.

39 Personal interview with the author, September 2006.

40 JVR to RFK, 5/4/1975, RFK/13/90/10/ R. KCC. As this letter is still classified as restricted, the Assistant Archivist at the Modern Archives Centre, King's College, Elizabeth Ennion, summed up the relevant content of this letter, for which I am very grateful.

41 Ibid.

42 J. Vaizey to M. Thatcher, 17/2/1975, Vaizey Mss. Hoover Institution, Stanford.

43 J. Vaizey to M. Thatcher, 16/1/1975, and M. Thatcher to J. Vaizey, 3/2/1975, Vaizey Mss. Hoover Institution, Stanford.

44 JVR to RFK, 14/4/1975, RFK/13/90/10/144, KCC.

45 JVR to RFK, 7/4/1975, RFK/13/90/10/156, KCC.

46 'A Dream World-Joan Robinson bursts the bubble of orthodox economics', Lot's Wife, 15(7), 21 April 1975, pp. 6-7. 
47 The Mont Pelerin Society, founded in 1947 by Friedrich von Hayek and other European intellectuals, was a think-tank which espoused libertarian economics (Cockett, 1995, pp. 100-21).

48 Personal communication with the author, July 2005.

49 JVR to RFK, 15 /4/1975, RFK13/90/10/142-3, KCC.

50 JVR to RFK, 15 /4/1975, RFK/13/90/10/142-3, KCC.

51 JVR to RFK, 24/3/1975, RFK/13 /90/10/166-7, KCC.

52 JVR to RFK, 26/4/1975, RFK/13/90/10/133, KCC.

53 JVR to RFK, 23/4/1975, RFK/13/90/10/138, KCC.

54 Monday Conference ABC transcript, No.141, 28 April 1975, p. 5.

55 Ibid.

56 Ibid., p. 7.

57 Ibid.

58 JVR to RFK, 26/4/1975, RFK/13/90/10/133, KCC.

59 H. W. Arndt to G. C. Harcourt, 8/1/1980, GCH, UA.

60 'Mainstream economics suffers unjust criticism, says Professor Snape', Monash Reporter, 40, June 4, 1975, p. 4.

61 Ibid.

62 Harcourt had been one of Vaizey's referees. Personal communication with

G. C. Harcourt, 30/8/2008.

63 Lot's Wife, 11/8/1975.

64 J. Vaizey to G. C. Harcourt, 13/ 8/1975, GCH, UA.

65 Ibid.

66 G. C. Harcourt communication with the author, 30/8/2008.

67 G. C. Harcourt to J. Vaizey, 2/9/1975, GCH, UA.

68 M. Thatcher to J. Vaizey, 11/7/1975, Vaizey Mss, Hoover Institution, Stanford.

69 J. Vaizey to G. C. Harcourt, 20/11/1975 GCH, UA. Vaizey sent Harcourt a typescript copy of the interview.

\section{References}

\section{Unpublished}

Richard Kahn Papers (RFK), Modern Archives, King's College, Cambridge University.

Joan Robinson's Papers (JVR), Modern Archives, King's College, Cambridge University.

Geoffrey C. Harcourt Papers 1950-1982, Manuscript 0007, University of Adelaide. John Vaizey Papers, Hoover Institution Archives, Stanford.

National Archives of Australia: A5915/ Cabinet Submission 1534.

Australian Broadcasting Corporation Monday Conference: Professor Joan Robinson Transcript No.141, 28 April 1975.

Secondary

Anon. 1970. 'Review: The Optimum Quantity of Money and Other Essays', The Economist, 3 January, p. 37.

Cochrane, D. 1968. 'The faculty of economics and politics', Monash Reporter, 5(42), pp. 1-4.

Cockett, R. 1995. Thinking the Unthinkable: Think-tanks and the Economic Counter-Revolution 1931-1983. London: Harper Collins. 
Courvisanos, J. and Millmow, A. 2006. 'How Milton Friedman came to Australia: a case study of class based political business cycles’, Journal of Australian Political Economy, 57, pp. 112-36.

Dow, G. 2003. 'Joan Robinson 1903-1983', Journal of Australian Political Economy, 52, December.

Friedman, M. and Friedman, R. D. 1998. Two Lucky People: Memoirs. Chicago: The University of Chicago Press.

Galbally, R. 2004. Just Passions. Melbourne: Pluto Press.

Garnett, M. 2007. From Anger to Apathy: The British Experience since 1975. London: Jonathan Cape.

Groenewegen, P. 2004. Australian Economic Policy, Theory and History: R. C. Mills Memorial Lectures 1958-2003. Sydney: University of Sydney.

Gruen, F.H. 1971. 'The radical challenge to bourgeois economics', Australian Quarterly, 43(1), March, pp. 59-69.

Guttman, S. 2005. The Rise and Fall of Monetary Targeting. Melbourne: Australian Scholarly Publishing.

Harcourt, G. C. 1972. Some Cambridge Controversies in the Theory of Capital. Cambridge: Cambridge University Press.

Harcourt, G. C. 2007. 'Keith Septimus Frearson 1922-2000' in J. E. King (ed.), A Biographical Dictionary of Australia and New Zealand Economists. Cheltenham: Edward Elgar, pp. 106-9.

Hogbin, G. 2002. 'Ross McDonald Parish 24/12/1929-5/12/2001', Policy, 17(4), Summer, pp. 62-4.

Howarth, T. E. B. 1986. 'Introduction' to J. Vaizey, Scenes from an Institutional Life and Other Writings. London: Weidenfeld and Nicholson.

Hughes, B. 1980. Exit Full Employment: Economic Policy in the Stone Age. Melbourne: Angus and Robertson.

Kenyon, P. 2002. 'Obituary of Richard Hal Snape’, The Australian, 22 October.

King, J. E. 1997. 'Notes on the History of Post-Keynesian Economics in Australia', in P. Arestis, G. Palma and M. Sawyer (eds), Capital Controversy, Post Keynesian Economics and the History of Economic Thought. London: Routledge, pp. 298-309.

King, J. E. and Millmow, A. 2003. 'Death of a revolutionary textbook', History of Political Economy, 35(1), Fall, pp. 105-34.

Lindsay, G. 1996. 'The CIS at twenty: Greg Lindsay talks to Andrew Norton', Policy, 12(2), Winter, pp. 16-21.

McGuinness, P. P. 1975. 'Professor Joan Robinson, the first left-wing Keynesian economist in Australia, too', The National Times, 28 April 1975.

Nevile, J.W. and Stammer, D. W. (eds). 1972. Inflation and Unemployment: Selected Readings. Ringwood: Penguin Books.

Snape, R. H. 1979. 'Productivity, costs and employment', Australian Economic Review, 12(2), July, pp. 65-71.

Stilwell, F. 2006. 'The struggle for Political Economy at the University of Sydney', Review of Radical Political Economics, 38(4), Fall, pp. 539-50.

Strangio, P. 2002. Keeper of the Faith: a Biography of Jim Cairns. Melbourne: Melbourne University Press.

Vaizey, J. 1975. 'Political Economy and the Problems of our Time', 35th Joseph Fisher Lecture. Adelaide: Commercial Printing House. 
Vaizey, J. 1986. Scenes from an Institutional Life and Other Writings. London: Weidenfeld and Nicholson.

Williams, R. 2007. 'Donald Cochrane 1917-1983', in J.E. King (ed.), A Biographical Dictionary of Australia and New Zealand Economists. Cheltenham: Edward Elgar, pp. 54-7. 